УДК 347.1:340.132

DOI https://doi.org/10.32837/pyuv.v0i3(32).595

С. В. Завальнюк

orcid.org/0000-0002-3146-0216

кандидат юридичних наук, доиент,

доцент кафедри иивільного права

Національного університету «Одеська юридична академія»

\title{
ПРОГАЛИННІСТЬ ЯК ХАРАКТЕРНА ОЗНАКА ЦИВІЛЬНОГО ЗАКОНОДАВСТВА
}

Постановка проблеми. Більшість цивільно-правових норм спрямовано на позитивне регулювання особистих немайнових і майнових відносин їх учасників. Однак позитивне регулювання не завжди встигає за змінами суспільних відносин. Існуванню конкретних цивільно-правових відносин передує юридичний факт, під яким розуміють такі життєві обставини, з якими норми права пов'язують виникнення, зміну чи припинення правових відносин.

Динаміка розвитку суспільства, науково-технічний прогрес, індивідуальні особистісні зміни вносять корективи в існуючі суспільні відносини та ініціюють появу нових юридичних фактів, на основі яких виникають нові відносини та значно трансформуються вже існуючі. Однак не лише поява нових юридичних фактів є причиною виникнення прогалин у законодавстві, адже змінюються умови життя; під час правозастосування виявляються помилки та недоліки юридичної техніки, допущені законодавцем, суперечливість, неузгодженість норм.

Аналіз останніх досліджень і публікацій. Дослідження питання правової природи правових прогалин так чи інакше у своїх працях розглядали Р. Авалян, В.М. Жуйков, О.М. Калашник, Н.С. Каранина, А.Я. Курбатов, В.В. Лазарєв, І.А. Маньковський, П.В. Марков, Ю.І. Матат, В.А. Микрюков, А.В. Поляков, I.I. Поляков, А.А. Степанюк, Т.А. Трубіцина, Є.Н. Трубєцкой, Л.А. Фоміна, Є.О. Харитонов, Л.Л. Чантурія, Л.С. Явич та багато інших. Однак більшість із вказаних авторів, досліджуючи питання прогалин, майже завжди ототожнювали поняття «прогалини у праві» i «прогалини у законодавстві». Також більшість із них зовсім не розглядали цивільно-правовий аспект поставленого питання, що надає цій статті ще більшої актуальності.

Постановка завдання. Метою статті є дослідження прогалин у цивільному законодавстві України, вивчення прогалинності як невід'ємної характерної ознаки цивільного законодавства, визначення її природи та причин виникнення.

Виклад основного матеріалу. Перед початком викладення матеріалу дослідження слід презюмувати використане у попередніх дослідженнях визначення «прогалини у цивільному законодав- стві» як відсутність нормативного врегулювання цивільних відносин, що виражається у відсутності належної норми в законах України, чинних міжнародних договорах України, згода на обов'язковість яких надана Верховною Радою України, а також постановах Верховної Ради України, указах Президента України, декретах і постановах Кабінету Міністрів України, прийнятих у межах їх повноважень і відповідно до Конституції України та законів України. Варто зазначити, що більшість авторів, які досліджували проблематику прогалин, навмисно чи несвідомо використовували легістський підхід до розуміння поняття «права», тому в своїх твердженнях вони ототожнювали поняття «прогалини у праві» і визначені нами «прогалини у законодавстві».

Не можна оминути увагою той факт, що більшість цивільно-правових норм спрямована на позитивне регулювання особистих немайнових і майнових відносин їх учасників. Однак позитивне регулювання не завжди встигає за змінами суспільних відносин. Виникненню конкретних цивільно-правових відносин передує юридичний факт, під яким розуміють такі життєві обставини, 3 якими норми права пов'язують виникнення, зміну чи припинення правових відносин. Динаміка розвитку суспільства, науково-технічний прогрес, індивідуальні особистісні зміни вносять корективи в існуючі суспільні відносини та ініціюють появу нових юридичних фактів, на основі яких виникають нові відносини та значно трансформуються вже існуючі.

Соціальна структура суспільства характеризується крайньою розгалуженістю, наявністю численних соціальних груп (партії, класи, соціальні верстви), які є носіями сепаратних і нерідко суперечливих один одному інтересів. Реалізуючи свої інтереси, окремі групи вступають у різні відносини між собою, причому далеко не завжди такі відносини не суперечать законодавству ( «дозволено все, що прямо не заборонено законом») і врегульовані чинними правовими нормами [17, с. 3].

Поява нових суспільних відносин, якщо вони входять у предмет правового регулювання, потребує нормативного врегулювання шляхом внесення доповнень і поправок до чинного законодавства. Нерідко цей процес потребує наукового осмис- 
лення для формування теоретичного розуміння явищ, процесів, відносин, що є супутніми до тих відносин, які потребують правового регулювання. Для встановлення законного, єдиного та об'єктивного (правового) режиму відносин, що виникли, юристам-науковцям необхідно звернутися до досягнень інших наук (технічних і суспільних), адже кожні відносини специфічні і відображають певну сферу людської діяльності.

Цивільне право регулює найбільш динамічну та стрімко змінювану сферу суспільного життя. Вплив науково-технічного та суспільного прогресу також накладає свій відбиток на будь-які приватноправові відносини. Сам же приватний характер відносин передбачає диспозитивність їх правового регулювання. Все перераховане вище обгрунтовує стурбованість вітчизняного законодавця проблемою подолання прогалин цивільного законодавства. Процес удосконалення правового регулювання здійснюється безперервно як шляхом внесення змін до чинного законодавства, так і на рівні правозастосування.

Однак не лише поява нових юридичних фактів є причиною виникнення прогалин у законодавстві, адже змінюються умови життя; під час правозастосування виявляються помилки та недоліки юридичної техніки, допущені законодавцем, суперечливість, неузгодженість норм. Варто зазначити, охоплення всіх життєвих обставин у цивільному праві за допомогою норм законодавства не можливе, зокрема, за умов, коли існує законодавче врегулювання конкретних цивільних відносин, проте абстрактний характер норми не надає можливості наперед передбачити всі ймовірні випадки, які можуть траплятися під час її реалізації $[4$, с. 36$]$.

Посилаючись на Великий тлумачний словник української мови, А.А. Степанюк зазначила, що слово «прогалина» має декілька значень. Так, прогалиною є проміжок між чим-небудь, простоpe, вільне від дерев, хлібів, рослинності місце на узліссі, серед лісу, в саду, в полі; у переносному значенні це слово означає «упущення», «пропуск» [14, с. 18]. Водночас упущення характеризується як те, що не зроблено, не виконано вчасно, а пропуск - як відсутність кого-, чого-небудь внаслідок проминання [2, с. 36]. Очевидно, що для права підходить останнє значення цього слова. Тому прогалиною у праві називають повну або часткову відсутність (неповноту) правового врегулювання суспільних відносин у межах предмета фактичного правового регулювання, встановленого законодавцем [2, с. $1155,1172,1520]$.

Явище прогалинності позитивного права (законодавства) відомо з давніх-давен. Ще Аристотель вказував, що закон не може передбачити всі можливі конкретні випадки життя, але за необхідності слід виправити недолік і заповнити прогалину
[13, с. 20] (Політика, кн. III, гл. 11; Риторика, кн. I, гл. В).

На думку А.В. Полякова, наявність прогалин у праві зумовлена прорахунком законодавця при прийнятті нормативно-правових актів чи еволюційними змінами в суспільних відносинах, які в такій ситуації не можливо було передбачити [12, с. 582-583]. На підтвердження цієї думки Л.Л. Чантурія зазначає, що під час розробки кожного закону його автори спираються на ті знання та досвід, які вони мають на час розробки певного закону. Тому вони не можуть передбачити всі життєві випадки. Жииття часто породжує такі проблеми, для вирішення яких законодавцем не передбачено жодної конкретної норми [19, с. 77].

T.А. Трубіцина зазначає, що природа пробільності законодавства досить складна. Крім утворення нових суспільних відносин, сюди ж слід відносити неповний або неточний виклад волі законодавця у процесі конструювання норм, недостатність використання засобів юридичної техніки тощо [15, с. 31]. За формальної відсутності прогалин наявні цивільно-правові норми можуть виявитися дефектними, тобто технічно неякісними, неповними, суперечливими, невиразними, що буде сигналізувати про наявність прогалини по суті [11, с. 134].

Р. Авалян зазначає, що наявність прогалин може бути зумовлена трьома факторами. Перший фактор - це недоліки того чи іншого нормативного правового акта, інститутів або галузей права. Йдеться про ті випадки, коли законодавець із різних причин не зміг врегулювати правом якісь суспільні відносини, хоча об'єктивна потреба в цьому існує. Причини такої неврегульованості можуть бути різними: від недоліків юридичної техніки до особливих політичних та (або) економічних умов. Наявність у праві таких прогалин вкрай небажана і говорить про його недосконалість.

Другим фактором є свідома «відмова» законодавця регулювати будь-які відносини нормами права. А.С. Піголкін наводить такий приклад: якщо особа, яка виграла у лотерею якусь річ, i, отримавши її, виявила в ній істотні недоліки, то вимога усунути їх, безумовно, буде носити правовий характер, хоча конкретної норми, яка встановлює порядок вирішення такої претензії, не існує. У прийнятті норми, яка регулювала б це правовідношення, просто немає необхідності. Третій фактор полягає у відставанні права від змінених і нових суспільних відносин, які потребують нормативно-правової регламентації. Прогалини, викликані цим фактором, об'єктивно неминучі [1, с. 49-50].

Систематизуючи причини утворення прогалин у праві, Л.С. Явич виділяє такі джерела прогалин у праві: недогляд законодавця; відсилки до актів, які не прийняті; неврегульованість порядку засто- 
сування закону; навмисні спрощення; неминуче відставання законодавства від суспільних відносин, що розвиваються більш динамічно; помилки і спрощення самого законодавця, низький рівень його законотворчої культури [20, с. 143].

Прогалинність законодавства - це не тільки загальнотеоретична, але i прикладна проблема, пов'язана з вибором варіанту поведінки суб'єкта правозастосовної діяльності при вирішенні певної життєвої ситуації.

Поширеною є думка, що чим ширше законодавство, тим менше у ньому прогалин. Прихильники такого підходу знаходять панацею від прогалин у спеціальному законодавстві чи підзаконних актах. Однак таке твердження є щонайменше спірним. На підтримку такої думки виступає Д.О. Туманов, який стверджує, що «зростаюча кількість нормативних правових актів, які регулюють різні сфери суспільного життя, не свідчить про зменшення числа правових прогалин, а навіть певною мірою зумовлює їх появу. Законодавство обширне, але найчастіше неякісне з багатьох причин, насамперед у зв'язку із дефектом законодавчої техніки» [16, с. 5].

B.M. Жуйков зазначає, що прогалини у праві були, є і будуть завжди, як би законодавець не хотів і не вмів приймати необхідні закони, оскільки передбачити усі відносини, які потребують законодавчого регулювання, просто не можливо. В окремі історичні періоди навіть стабільне і добре розвинене законодавство починає кардинально оновлюватися, що неминуче тягне за собою зростання прогалин у регулюванні дуже важливих відносин [3, с. 147].

На думку В.В. Лазарєва, межі правового регулювання та сфера дії чинних нормативних актів перетинаються, але не збігаються. Обов'язково буде певна частина суспільних відносин, які не регламентовані правовими нормами, хоча перебувають у сфері правового регулювання [7, с. 13].

Щодо цивільного законодавства, то слушним є твердження Є.О. Харитонова про те, що в сучасних умовах попри зростаючу кількість законодавчих актів, законів і навіть кодексів більш очевидною стає неможливість і недоцільність всеохоплюючого регулювання суспільних відносин, надто у сфері цивільного обігу [18, с. 78-79].

Як зазначає I.O. Маньковський, стосовно цивільно-правового регулювання наявність прогалин, тобто відсутність правової норми, що підлягає безпосередньому застосуванню до суспільних відносин, що фактично склалися між суб'єктами цивільного права і відповідають ознакам цивільно-правових відносин, здебільшого зумовлено еволюційними змінами суспільних відносин, ніж прорахунками законодавця [8, с. 51]. Ця теза не $€$ однозначною, адже вчені неодноразово вказували саме на свідому недостатню розробку законо- давцем окремих положень цивільного законодавства, що зумовлено специфікою сфери правового регулювання цивільного права. Диспозитивний характер цивільно-правового регулювання, окрім дозвільно-договірного характеру врегулювання відносин між сторонами, передбачає і переважне невтручання й недопущення формалізації цивільно-правових відносин законодавцем.

Деякі автори висловлюють думку, що наявність правових прогалин насамперед характеризує континентальну правову систему [5]. Із цим твердженням не можна погодитися, адже наявність судового прецеденту як джерела права лише надає додаткового способу подолання прогалин, які все ж існують і в англосаксонській правовій системі. Таку ж думку зустрічаємо у дослідженнях, присвячених прецедентному праву [6; 10, с. 7].

Як приклад можна навести постанови Верховного Суду канадської провінції Британська Колумбія (Wiebe v. Wiebe (1980), Carmichael v. Carmichael (1985), якими було відмовлено у позовах про стягнення аліментів, заявлених жінками, які перебували у «фактичному шлюбі», до колишніх чоловіків, оскільки інше рішення призвело б до «невиправданих збитків» колишніх чоловіків i до безпідставного збагачення їх співмешканок. У цьому випадку суд, констатувавши прогалину, за аналогією права сформулював норму самостійно, «з урахуванням принципів природного права» (як було зазначено у рішеннях) [9].

Висновки. 3 урахуванням усього наведеного вище стає очевидним, що природа цивільного законодавства передбачає невідворотність виникнення у ньому прогалин. Тому можна впевнено виділяти прогалинність як окрему характерну ознаку цивільного законодавства.

\section{Jimepamypa}

1. Авалян Р. Аналогия в гражданском праве: вопросы теории и практики. Юрист ВУЗа. 2009. № 6. C. $47-52$.

2. Великий тлумачний словник сучасної української мови (з дод. і допов.) / Уклад. і голов. ред. В.Т. Бусел. К.; Ірпінь : ВТФ «Перун», 2005. 1728 с.

3. Жуйков В.М. Судебная защита прав граждан и юридических лиц. М. : Гордец, 1997. 320 с.

4. Калашник О.М. Прогалини у праві: юридична природа, їх ознаки та види. Юрист України. 2013. № 1(22). C. $36-42$.

5. Каранина Н.С. Проблемные вопросы применения закона по аналогии [Електронний ресурс]. Актуальные проблелы юридической науки и правоприленительной практики. Киров, 2007. Ч. 1. URL: http://2aas.arbitr.ru/ novosti-iobzory/nashi-publikacii/20080824-1.

6. Курбатов А.Я. Прецедентное право в России: пренебрежение к законам и усугубление проблем правоприменения [Електронний ресурс]. Закон. 2011. № 4. URL: https://publications.hse.ru/en/articles/68694922.

7. Лазарев В.В. Пробелы в праве и пути их устранения. М. : Юрид. л-ра, 1974. 184 с. 
8. Маньковский И.А. Аналогия как способ преодоления пробелов в гражданско-правовом регулировании. Право.by. 2013. № 5. С. 51-54.

9. Марков П.В. Условия осуществления судебного усмотрения в странах континентальной и англосаксонской правовой семи. [Электронный ресурс]. Юридиче ские исследования. 2012. № 4. URL: https://e-notabene. $\mathrm{ru} / \mathrm{lr} /$ article 318.html.

10. Матат Ю.І. Роль юридичного тлумачення норм права в механізмі подолання прогалин у законодавстві. Проблели законності. 2011. Вип. 116. С. 3-9.

11. Микрюков В.А., Микрюкова Г.А. Некоторые вопросы применения гражданского законодательства по аналогии. Вестник Перлского университета. 2014. Вып. 1(23). С. 133-144.

12. Поляков А.В. Общая теория права : курс лекций. СПб : Юрид. Центр Пресс, 2001. 642 с.

13. Поляков И.И. Проблема пробелов в законодательстве Украины. Правовые проблелы развития совреленной Украины : материалы межвуз. науч.-практ. конф. (май 2004 года), 2005. С. 19-22.

14. Степанюк А.А. Прогалини регулювання міжнародного приватного права. Адвокат : Загальнодерж. період. вид., 2005. № 8. С. 18-22.

15. Трубицына Т.А. К вопросу о применении судами права по аналогии. Российский судья. 2006. № 12. C. $31-35$.

16. Трубецкой Е.Н. Лекции по энциклопедии права [Електронний ресурс]. М. : Тип. А.И. Мамонтова, 1917.227 c.

17. Фомина Л.А. Аналогия закона и аналогия права в системе способов преодоления пробелов гражданского права : автореф. дисс. на соискание учен. степени канд. юрид. наук: спец. 12.00.03 «Гражданское право; предпринимательское право; семейное право; международное частное право». М., 2009. 27 с.

18. Харитонов Є.О. «Прогалини» у цивільному законодавстві: хиби правотворчості чи прийом законодавчої техніки. Юридичний вісник. 2013. № 1. C. $72-81$.

19. Чантурия Л.Л. Введение в общую часть гражданского права (сравнительно-правовое исследование с учетом некоторых особенностей постсоветского права). M. : Статут, 2006. 349 c.

20. Явич Л.С. Общая теория права. Л. : Изд-во ЛГУ, 1976. 298 с.

\section{Анотація}

Завальнюк С. В. Прогалинність як характерна ознака цивільного законодавства. - Стаття.

Більшість цивільно-правових норм спрямована на позитивне регулювання особистих немайнових i майнових відносин їх учасників. Однак позитивне регулювання не завжди встигає за змінами суспільних відносин. Виникненню конкретних цивільно-правових відносин передує юридичний факт, під яким розуміють такі життєві обставини, з якими норми права пов'язують виникнення, зміну чи припинення правових відносин.

Динаміка розвитку суспільства, науково-технічний прогрес, індивідуальні особистісні зміни вносять корективи в існуючі суспільні відносини та ініціюють появу нових юридичних фактів, на основі яких виникають нові відносини та значно трансформуються вже існуючі. Однак не лише поява нових юридичних фактів $е$ причиною виникнення прогалин у законодавстві, адже змінюються умови життя; під час правозастосування виявляються помилки та недоліки юридичної техніки, допущені законодавцем, суперечливість, неузгодженість норм.
Дослідження питання правової природи правових прогалин так чи інакше у своїх працях розглядали Р. Авалян, В.М. Жуйков, О.М. Калашник, Н.С. Караніна, А.Я. Курбатов, В.В. Лазарєв, І.А. Маньковський, П.В. Марков, Ю.І. Матат, В.А. Микрюков, А.В. Поляков, I.I. Поляков, А.А. Степанюк, Т.А. Трубіцина, Є.Н. Трубецька, Л.А. Фоміна, Є.О. Харитонов, Л.Л. Чантурія, Л.С. Явич та багато інших. Однак більшість із вказаних авторів, досліджуючи питання прогалин, майже завжди ототожнюють поняття «прогалини у праві» i «прогалини у законодавстві». Також більшість із цих авторів зовсім не розглядали цивільно-правовий аспект поставленого питання, що надає вказаній статті ще більшої актуальності.

У статті досліджено причини виникнення прогалин у цивільному законодавстві України. Автор дійшов висновку, що природа явища законодавства передбачає невідворотність виникнення у ньому прогалин, а тому доречним є твердження про визначення прогалинності як окремої ознаки цивільного законодавства.

Ключові слова: акт цивільного законодавства, законодавство, прогалини в цивільному законодавстві, прогалинність, цивільне законодавство, цивільне право.

\section{Summary}

Zavalniuk S. V. Gaps as a characteristic feature of civil legislation. - Article.

Most civil legal norms are aimed at the positive regulation of the personal non-property and property relations of their participants. However, positive regulation does not always keep pace with changes in social relations. The emergence of specific civil-law relationships is preceded by a legal fact, which is understood to mean the life circumstances to which the rule of law relates to the emergence, change or termination of legal relations.

The dynamics of social development, scientific and technological progress, individual personal changes make adjustments to existing social relations and initiate the emergence of new legal facts, on the basis of which new relationships emerge and significantly transform existing ones. However, not only the emergence of new legal facts is the cause of gaps in legislation, but life conditions are changing; during the implementation of the law, errors and shortcomings of the legal technique made by the legislator, inconsistency, inconsistency of norms are revealed.

The study of the legal nature of legal gaps was considered in one way or another in their works Avalan R., Zhuikov V.M., Kalashnik A.N., Karanina N.S., Kurbatov A.Ya., Lazarev V.V., Mankovsky I.A., Markov P.V., Matat Yu.I., Mikryukov V.A., Polyakov A.V., Polyakov I.I., Stepanyuk A.A., Trubitsyna T.A., Trubtskoy E.N., Fomin L., Kharitonov E.O., Chanturia L.L., Yavich L.S. and many others. However, the vast majority of these authors, when examining the issue of gaps, almost always identify the concept of gaps in law and gaps in legislation. Also, most of these authors did not consider the civil law aspect of the question at all, which makes this article even more relevant.

The article investigates the causes of gaps in the civil legislation of Ukraine. The author has come to the conclusion that the nature of the phenomenon of the law provides for the inevitability of the appearance of gaps in it, and then, the statement about the definition of permeability as a separate feature of the civil legislation is appropriate.

Key words: act of civil law, legislation, gaps in civil legislation, gaps, civil legislation, civil law. 